leaves makes it probable that radioactive urea is hydrolysed by urease in the leaves of the Coffea tree. A more detailed report of these experiments will be published later ${ }^{2}$.

This work was supported by the Atomic Energy Commission of the Swiss National Research Foundation.

Institute of General Botany, Peter Kalberer

University of Zurich, Switzerland.

${ }^{1}$ Wanner, H., Alkaloid-Symposium, Halle (Saale), 1980.

Kalberer, P., Ber. Schweiz. Bot. Ges. (in the press).

\section{Solubilization of Keratins by Reaction with Ethylene Oxide}

THE reactions of keratins and other proteins with epoxides have been described by several investigators'. The chemical modification of wool by reaction with mono- or di-functional epoxides in aqueous or alcoholic solution at or near room temperature has also been studied. In general, the acid and alkali solubility is decreased by reaction with di-functional opoxides, but incroased if a monofunctional epoxide is employed ${ }^{2}$. We have recently found, however, that quite difforent results are obtained if wool is heated with ethylene oxide and a small amount of $N, N$-dimethylaniline with no solvent, as described by Haas et al. ${ }^{3}$ for malking hydroxyethyl nylon. Under these conditions, the wool fibres are disintegrated and the product is soluble in water. Part of the ethylene oxide does not react and part is converted to polyethylene glycol which can be extracted from the aquoous solution with mothylene chloride or toluene, although the latter solvent forms troublesome emulsions which are much more persistent than those formed by methyleno chloride. A very small part of the ethyl ${ }^{\prime}$ e oxide apparently becomes attached to the solu. bilized wool.

As an example, $0.960 \mathrm{~g}$ wool cloth was sealed in a glass tube with $10 \mathrm{ml}$. ethylene oxide and $0.1 \mathrm{~g} N, N$-dimethylanilino in a nitrogen atmosphoro (no special precautions were taken to include or exclude moisture) and heated at $80^{\circ} \mathrm{C}$ for $25 \mathrm{~h}$. The viscous, syrupy reaction product was washed out of the tube with water, and the resulting aqueous solution was exhaustively extracted in a continuous extractor with methylone chloride. The syrupy extract weighed $6 \cdot 2 \mathrm{~g}$. The aqueous phase was clarified by centrifuging; the residue in the centrifuge tube, on drying, gavo a solid that weighed $2.9 \mathrm{mg}$. Tho weight of the water-soluble, methylene chloride-insoluble fraction, estimated by drying an aliquot to constant weight, was $1 \cdot 724$ g. John J. Bartulovich, of this Iaboratory, found by ultracentrifugation (in a preliminary determination by the Archibald method) that the material not extracted from the aqueous solution by methylono chloride had a weight average molecular weight of about 10,000 . Wilfred $H$. Ward, also of this laboratory, found that the matorial passed through a dialysis membrano, which indicated that the molecular weight cannot greatly exceed 10,000. The precise extent of degradation of the protoin thuss romain to be determined.

Other fibrous proteins solubilized by this procedure are: mohair, ovokeratin, eattlo horn, and silk fibroin. In one trial with fibroin, complete solubilization was obtained, but in others only one-fifth or one-fourth of the silk was solubilized. The insoluble silk romaining after the reaction with ethylono oxide and $N, N$-dimethylaniline retained tho fibrous appearance and structure.

When wool that has recoived a polyamide treatment applied by the intorfacial polymerization proceduro* is nsod, the wool is solubilized and the polyamide shoath is undissolved.

Work is in progress on the nature of the water-soluble reaction product resulting from the reaction of ethylene oxide with the protein, and the procedure may be useful in fundamental keratin studies.

W. G. Rose

Western Regional Rosearch Laboratory,

Agricultural Research Service,

U.S. Department of Agriculture, Albany, California, 94710.

${ }^{2}$ Olcott, H. S., and Fraenkel-Conrat, H., Chem. Heviews, 41, 151 (1047); Fraenkel-Conrat, H., J. Biol. Chem., 154, 227 (1944).

${ }^{2}$ Capp, C. W., and Speakman, J. B., J. Soc. Dyers and Colorourists, 65 , 402 (1949); Fearnley, C., and Speakman, J. B., Nature, 166, 743 (1950): Rose, W. G., unpublished work.

${ }^{3}$ Haas, H. C, Cohen, S. G., Oglesby, A. C., and Karlin, E. R., J. Polymer Science, 15, 427 (1955)

- Whittield, R. E., Miller, I. A., and Wasley, W. L., Text. Res. J., 31, 704 (1961).

\section{Estimation of Urinary Oxalate by the Method of Isotope Dilution}

DuRINe the course of a series of metabolic experiments in which $1 .{ }^{18} \mathrm{C}$-ascorbic acid and $1 .{ }^{13} \mathrm{C}$-glycine were fed to a normal adult ${ }^{1}$ and hyperoxaluric patients ${ }^{2}$ daily samples of urinary oxalic acid were isolated as calcium oxalate for estimation of the ${ }^{13} \mathrm{C}$ enrichment. It was found expedient to determine the daily levels of excretion by the method of isotope dilution, using the specific ${ }^{14} \mathrm{C}$-activity of the oxalate samples prior to combustion to $\mathrm{CO}_{2}$ for mass spectrometric analysis. The amounts of ${ }^{14} \mathrm{C}$ and ${ }^{12} \mathrm{C}$ added were low and hence did not interfere with the measurement of ${ }^{13} \mathrm{CO}_{2}$. Previously reported methods for calcium oxalate estimation have the disadvantage that they depend on the complete recovery of oxalate from a sample of the urine ${ }^{3-7}$. Using the method of isotope dilution, however, the only exacting requirement is the purity of the final product, which is checked by repeated reprocipitation to constant specific activity.

Twenty-four-hour urine collections were made in $40 \mathrm{ml}$. of $6 \mathrm{~N} \mathrm{HCl}$, and after the addition of $1: 2{ }^{14} \mathrm{C}$-oxalic acid (1 $\mu \mathrm{c} ., 0.2 \mu \mathrm{g})$ sufficient concentrated $\mathrm{HCl}$ was added to bring the concentration to $2 \mathrm{~N}$ and the whole was continuously extracted for $16 \mathrm{~h}$ with peroxide-free ether. The ether phase was evaporated in the presence of water $(5 \mathrm{ml}$.$) and the aqueous residue was treated with 0.880$ $\mathrm{NH}_{4} \mathrm{OH}$ (1-2 ml.). Saturated $\mathrm{CaCl}_{2}(0.5 \mathrm{ml}$.) was added and the precipitated $(\mathrm{COO})_{2} \mathrm{Ca}_{2} \mathrm{H}_{2} \mathrm{O}$ was purified by solution in $2 \mathrm{~N} \mathrm{HCl}(5-7 \mathrm{ml}$.), decolorization with 'Norit' and precipitation with $0.880 \mathrm{NH}_{4} \mathrm{OH}$ and acetic acid at $p \mathbf{H} 5 \cdot 2$ (brom-cresol purple). Samples were counted by the liquid scintillation technique (Nuclear Chicago Instrument, model 725) using $100-\mu$ l. aliquots (taken from the $\mathrm{HCl}$ solution prior to re-precipitation) and a dioxanbased phosphor (10 ml. 'Panax', type T.E.D.). At the concentration used $\left(0 \cdot 1-0.5 \mathrm{mg}\right.$ of $\left.(\mathrm{COO})_{2} \quad \mathrm{Ca} . \mathrm{H}_{2} \mathrm{O}\right)$ no quenching due to calcium oxalate was observed, and the counting efficiency was 51 per cent. The disintegrations per min were calculated from an efficiency curve established by adding different volumes $(25-300 \mu \mathrm{l}$.) of $2 \mathrm{~N} \mathrm{HCl}$ to a known radioactive standard (Packard, Standard Source Toluene ${ }^{14} \mathrm{C}$ ) in $10 \mathrm{ml}$, of phosphor and applying the 'Channels Ratio' method 8 . The purification process was roponted until the specific activity remainod constant (usually three re-precipitations were adequate). In some cases the purity of the final product was also checked by dissolving $1-2 \mathrm{mg}$ in $2 \mathrm{~N} \mathrm{H}_{2} \mathrm{SO}_{4}(5 \mathrm{ml}$.) and determining the oxalic acid by the method of Hodgkinson and Zarembskit. In any isotope dilution analysis the total amount of substance present is inversely proportional to its specific activity and the amount of urinary calcium oxalate was calculated from its specific activity, compared with that of a standard prepared from the same $1: 2^{-14} \mathrm{C}$-oxalic acid.

During metabolic experiments lasting 19 and 15 consecutivo days', a normal adult gave daily (COOH) $)_{2} \cdot 2 \mathrm{H}_{2} \mathrm{O}$ excretions of $41.8 \mathrm{mg}$. (S.D. $\pm 4.6 \mathrm{mg}$ ) and $26.7 \mathrm{mg}$ (S.D. $\pm 4.6 \mathrm{mg}$ ) respectively, whereas a hyperoxaluric 